\title{
The Development of Civil Engineering Projects and Village Communities in Seventeenth- to Nineteenth-Century Japan
}

\author{
Junichi Kanzaka
}

In Japan, civil engineering projects have played an important role in the development of agriculture. Building dikes, canals, and ponds substantially expanded the amount of irrigated land. Furthermore, draining lakes and the sea reclaimed a great deal of land. These investments in field expansion, as well as the rise in productivity per acre, contributed greatly to the advancement of agriculture in Japan (Ishikawa 1967, Booth and Sundrum 1985). It is true that, sometimes, village communities opposed civil engineering projects. However, in many cases, village communities promoted field expansion and land improvement projects in Japan. Indeed, at the beginning of the Tokugawa period, large-scale projects by governments often promoted the establishment of close-knit rural communities. Government projects encouraged the growth of villages consisting of autonomous small households. Thereafter, villagers accumulated wealth and began carrying out civil engineering projects by themselves. In the nineteenth century, village communities played a very important role in building facilities for irrigation, drainage, and reclamation. Villagers supported or initiated water management projects by making plans, providing labor, and, sometimes, funding capital. Furthermore, the close social network encompassing villages based on the water control system helped settle disputes among several villages. Prominent figures in regional society arbitrated many conflicts outside of government courts.

To examine the relationship between the development of civil engineering projects and the growth of village communities, section 2 of this chapter provides an overview of the increase in paddy acreage between the seventeenth century and the nineteenth in Japan, based on the database of civil engineering projects. Section 3 analyzes the relationship between the growth of villages and government 
civil engineering projects. Section 4 analyzes the communal functions of village communities and regional societies. Section 5 concludes the chapter.

\section{EXPANSION OF PADDY ACREAGE}

\section{Civil Engineering Projects}

This analysis examines the effect of several civil engineering projects by calculating the acreage of paddies created by each individual project. In Japan, cultivated land mainly consists of paddies where rice grows and dry fields where wheat and other crops grow. Since irrigated paddies are usually more productive than dry fields are, the Japanese community tirelessly built water management facilities to convert wastelands and dry fields to paddies. Three such facilities are especially important, namely, dikes, canals, and ponds. First, dikes were constructed to control the flow of rivers. Many Japanese rivers flowing from mountains frequently change their courses on alluvial fans and flood plains. Therefore, peasants began to cultivate the soil and build new villages on former flood plains only after the construction of dikes. Thereafter, they built canals along former river courses to irrigate new paddies. Second, canals were sometimes dug without building dikes. Long canals of more than ten thousand meters were often constructed using advanced techniques, such as topography analysis to let water go down shallow slopes and the construction of tunnels and siphons to lead water beyond all obstacles. Finally, ponds were constructed where sufficient water was not available from river flows. In some places, a sophisticated system for the connection of several ponds was developed to stabilize water supply (JSCE 1936).

In this way, the Japanese built several facilities to provide paddies with sufficient water. In 1907, the Ministry of Agriculture and Commerce of Japan investigated the hydrological condition of paddies (MAC 1909). In the 1910s, the Japanese began to use power pumps for irrigation and drainage. Furthermore, as explained later in more detail, in the 1920s, the government began to subsidize the cost of large civil engineering projects. Therefore, the investigation of developments in 1907 reveals the achievements of privately financed projects utilizing the natural flow of water, indicating the sources of irrigation and the manner in which sufficient water was provided. The survey shows $65.5 \%$ of $2,738,508$ hectares of paddies were irrigated by water coming from rivers. Almost all of this water is assumed to have been distributed through canals. Next, $20.7 \%, 5.3 \%, 1.3 \%$, and $1.0 \%$ of paddies were irrigated by ponds, fountains, wells, and lakes, respectively. In addition, the investigation indicates that $22.3 \%$ of paddies were irrigated plentifully, and $58.5 \%$ of paddies were irrigated properly. Therefore, more than $80 \%$ of paddies had sufficient water. Since the survey shows the data by district ( $g u n$ ), I calculate the river irrigation rate (hectares irrigated by rivers divided by total hectares) and the sufficient irrigation rate (the ratios of hectares irrigated plentifully, properly, and insufficiently were 


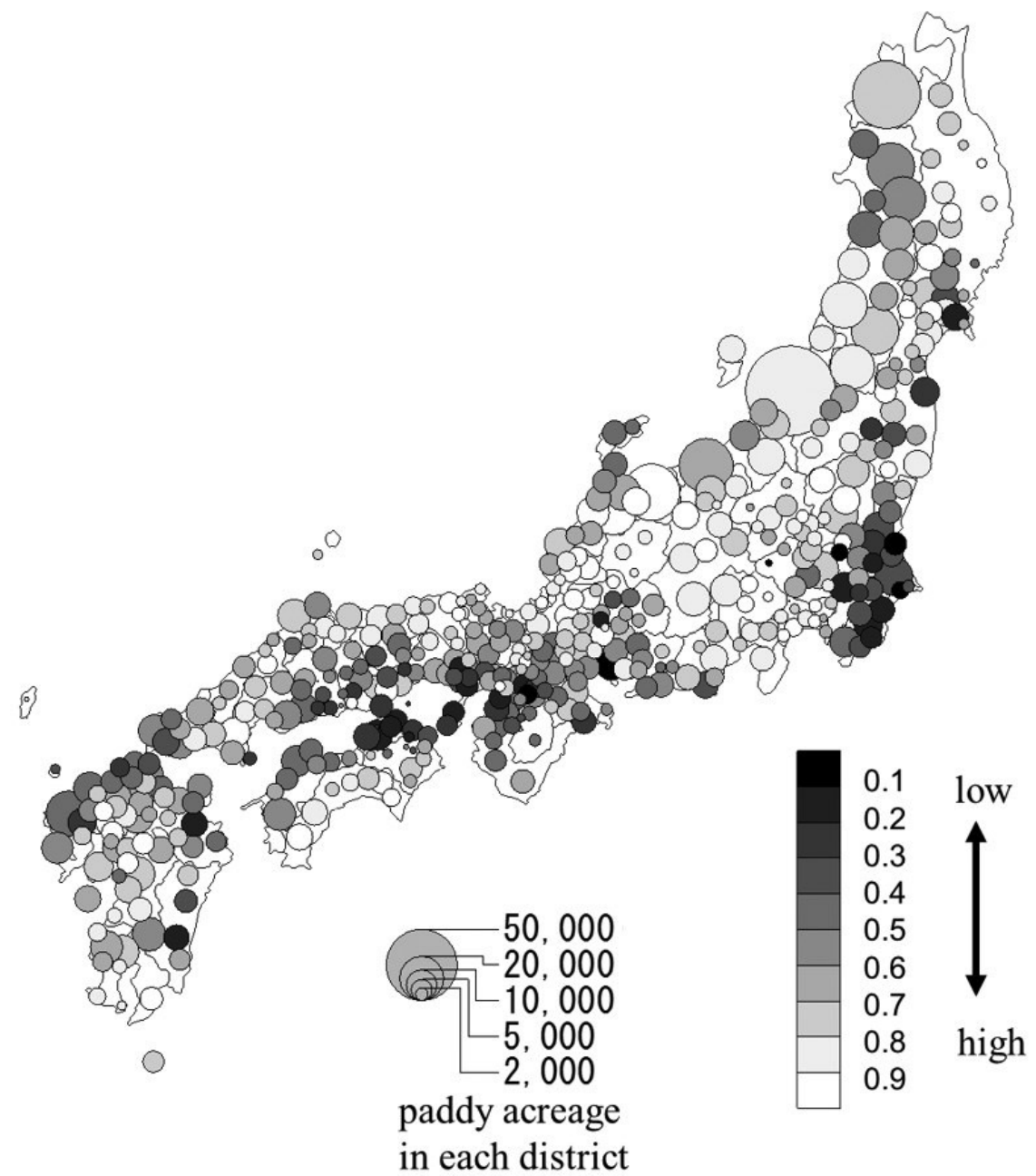

FIGURE 7. River Irrigation Rate in 1907

Source: Data from MAC 1909.

tentatively weighted by 1.0, 0.5, and 0.0, respectively, and summed), and I show the distributions of the two rates in figures 7 and 8 . On the one hand, figure 7 reveals that the river irrigation rate varied widely across districts. Each district adopted its own suitable method for irrigation. In the regions around the Seto Inland Sea and the Bōsō Peninsula, where there are no large rivers, ponds provided water to many paddies. On the other hand, figure 8 also shows that the sufficient irrigation rate was not so different between each district. It was less than 0.35 in only $9.1 \%$ of districts, and there was no area where districts with a lack of water supply 


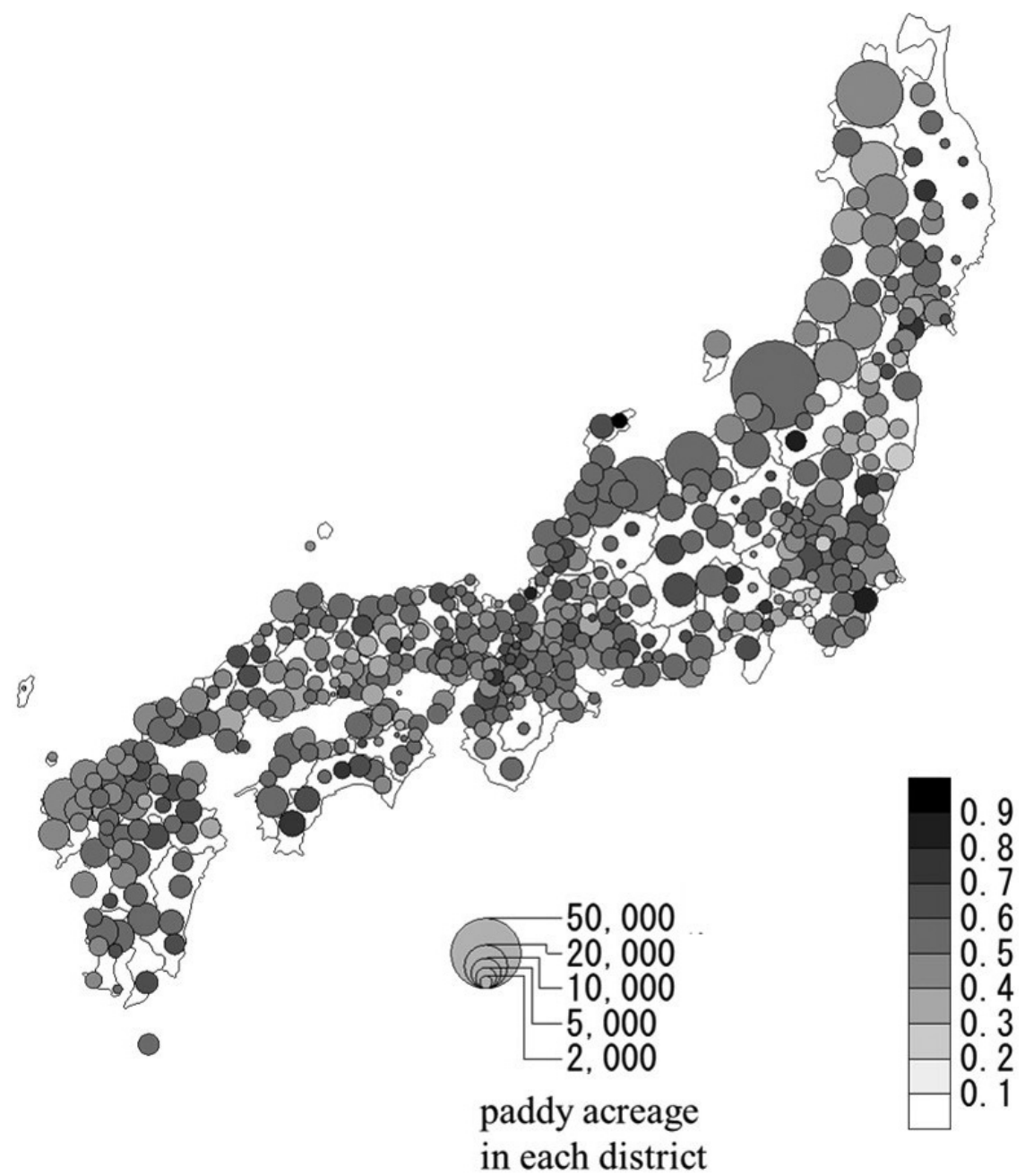

FIGURE 8. Sufficient Irrigation Rate in 1907 Source: Data from MAC 1909.

were concentrated. Until the beginning of the twentieth century, each individual district throughout Japan had developed its own appropriate irrigation system.

\section{Increase in Irrigated Paddies}

How did the Japanese expand the acreage of irrigated paddies? Since there are no comprehensive statistical data on arable land before 1874, I estimate the increase in paddy acreage before 1873 in two ways. First, the paddy acreage at the beginning 
and the end of the Tokugawa period was estimated based on existing historical documents. Following Miyamoto's calculation based on a land survey executed by Hideyoshi Toyotomi, who politically unified Japan's archipelago in the late sixteenth century, the total acreage of the arable land is estimated as 2,064,657 $c h \bar{o}^{1}$ at the end of the sixteenth century. Furthermore, assuming half of the arable land comprised paddies, the paddy acreage was 1,032,328 chō (Miyamoto 1999). ${ }^{2}$ Next, using data from the survey for Land Tax Reform by the Meiji Government, the acreages of total arable land and paddies in 1872 are calculated as $3,476,844$ chō and 1,842,066 chō, respectively (APDLTR 1953-1957). Therefore, paddy acreage increased by 809,738 cho during the Tokugawa period. However, these numbers are calculated according to $k y \bar{u}$-tanbetsu, or acreage measured by traditional methods. Meanwhile, the Meiji government eagerly reexamined the acreage of arable land by utilizing common national measures and adopting a strict approach to calculating acreage (Sasaki 2016, 311), and, as a result, the revised acreage (shintanbetsu) was $42.9 \%$ larger than former acreage ( $k y \bar{u}$-tanbetsu). ${ }^{3}$ Hence, the acreage in the Tokugawa period may have been underestimated in comparison with that in the later period.

Second, the growth in paddy acreage is estimated based on the data of each individual civil engineering project. In 1926, the Ministry of Agriculture and Commerce of Japan conducted its survey of civil engineering projects in the Tokugawa era in order to examine the origins of customary irrigation rights (MAC 1926). A decade later, the ministry's research was revised by the Japanese Society of Civil Engineering, and the number of listed projects increased from about 1,171 to 1,585 . Based on the revised survey, Miyamoto $(1999,38)$ estimates the acreage of cultivated land, and Nakamura (1968) calculates the "real amount of production" in Tokugawa Japan. Nevertheless, the estimates are insufficient because they simply count the number of construction projects, ignoring the scale of each. Therefore, as to 2,857 projects registered by the two surveys (MAC 1926, JSCE 1936), and some other documents (Akita-ken ECLIH 1985, Ishikawa-ken ECLIH 1986, Niigata-ken ECLIH 1986, Toyama-ken ECLIH 2004), I built a database recording information on who carried out each project, when it was accomplished, and how many acres were affected in the process. The total acreage of the affected area of the listed projects is 492,203 cho ; this total accounts for $58.0 \%$ of the aforementioned paddy expansion during the Tokugawa period. Since villagers often increased their production simply by expanding their paddies to the adjoining land (kirizoe-shinden) without records, the database of civil engineering projects does not fully capture the activities of peasants. Nevertheless, the accumulated acreage data of affected individual projects can be assumed to indicate the principal trend of paddy expansion.

The database reveals that there were three periods of paddy expansion from the end of the sixteenth century to the nineteenth century. ${ }^{4}$ Figure 9 shows the increase of paddy acreage in the Tokugawa period. First, until around 1680, paddy 


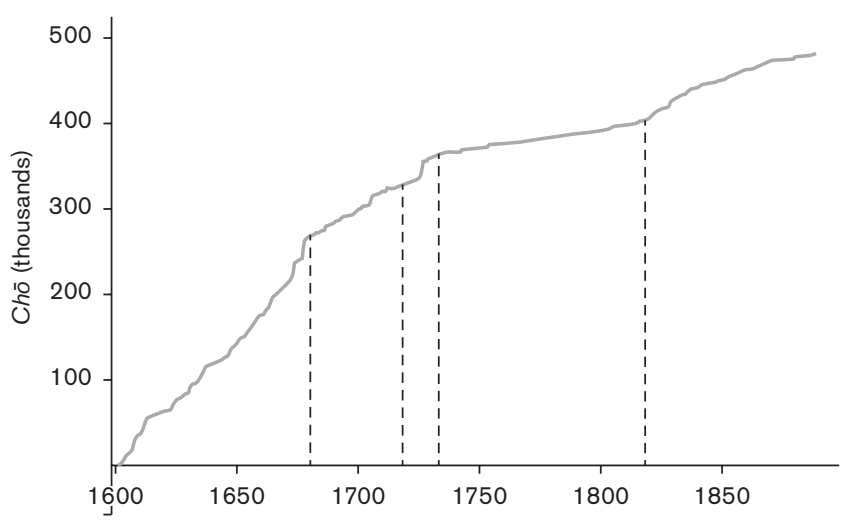

FIGURE 9. Increase of Paddy Acreage of Tokugawa Japan Source: The database mentioned in the text.

acreage expanded greatly. This expansion is sometimes called the "great reclamation" and is considered to have begun in the sixteenth century in advanced regions (Saito 1988, 173). Public investment in controlling rivers and the construction and maintenance of canals and ponds converted barren wasteland into fertile paddies and fields. In the early seventeenth century, local governments carried out many large projects to improve public infrastructure, which stabilized the production of peasant households and encouraged them to create a close-knit community.

However, the growth hit an environmental limit. Since severe deforestation due to paddy expansion as well as logging for a construction boom had caused landslides and floods by the late seventeenth century, the shogunate and the domain government restrained paddy expansion. For example, in 1666, the shogunate government issued the Regulation for Conserving Mountain and Rivers (Shokoku-sansen-okite) to prevent erosion and floods in the Kinai region, and it prohibited deforestation in the mountains and encouraged tree planting (Totman 1998). Then, from the 168 os onward, the growth in paddy acreage slowed down. The second period of paddy expansion began with an announcement by the shogunate government to encourage the creation of new paddies in 1722 (Kimura 1964, 58). In this period, governments carried out large-scale public works, such as reclaiming land from lakes. For example, Yasubee Izawa, a shogunate official, directed the reclamation of Minuma and Iinuma in 1727, and that of Shiunji in 1733. Nevertheless, the development did not last very long. Paddy expansion stagnated for about eighty years from 1736 to the 1810 s. Then, in the 1820 s, the third period of paddy acreage expansion began. Paddy acreage increased mainly as a result of the construction of canals and reclamation of land from the sea. Village communities that had accumulated wealth played an important role at this stage. This expansion continued beyond the Meiji Restoration in 1868, and ended in 1880. Thereafter, a slow-down period lasted until 1905. 


\section{Growth of Productivity}

The civil engineering projects not only increased the acreage of paddy fields but also laid the foundation for the growth of land productivity per acre. Tokunaga (1997) states that agricultural development in Tokugawa Japan consisted of three phases: namely, the construction of irrigation facilities, greater input of fertilizer, and the amelioration of cultivation tools. "Since agricultural production is based on natural factors such as land, water, and plants, we should build water management infrastructure first" (Tokunaga 1997, 15). Then, on the well-irrigated paddy fields, peasants started to apply fertilizer efficiently, and practiced deep tillage. In fact, after many great civil engineering projects were accomplished in the seventeenth century, peasants raised the intensity of agricultural production. During the eighteenth and early nineteenth centuries, to increase fertilizer inputs, many peasants began to use purchased fertilizers, such as sardine meal and the residue from pressing oil. Furthermore, they developed a variety of hoes and sickles with specific uses for different stages of production (Miyamoto 1999, 46).

Since, as mentioned before, irrigation systems were developed throughout Japan, peasants were able to carry out intensive agriculture in almost all districts. As a result, land productivity grew in all of Japan and the gap in land productivity between advanced and backward regions reduced. In the early Tokugawa period, peasants in several provinces in western Japan yielded more than twice the amount of products than in the backward northeastern provinces. Nakamura (1968) estimates land productivity in each province (kuni) in 1700, by dividing kokudaka in 1697-1702 by the acreage of arable land in 1716-1747. Kokudaka are land values measured by the amount of estimated rice yield based on land surveys. Although, from the eighteenth century onward, the kokudaka usually underestimated the real quantity of output, ${ }^{5}$ kokudaka in $1697-1702$ is assumed to reflect actual products. In the early Tokugawa period, the average product per tan of seventy provinces (Echizen is excluded) ${ }^{6}$ was $0.94 \mathrm{koku}$, the standard deviation was 0.28 , and the coefficient of variation was 0.29 . Next, I estimate the land productivity in the beginning of the Meiji era based on governmental surveys on the yield of "paddy and non-glutinous rice" in 1877-1881 (Umemura et al. 1966, 38). The data reveal two facts. First, land productivity had increased during the eighteenth and nineteenth centuries. The average product per tan of seventy-one provinces was $1.31 \mathrm{koku}$, or $39 \%$ higher than what it was around 1700 . This must have been the result of the development of intensive cultivation. Second, the difference in the productivity among the provinces had reduced. The standard deviation of $k o k u$ per tan of seventy-one provinces was 0.26 , and the coefficient of variation was 0.20 , or $31 \%$ lower than what it was around 1700 . While the productivity in the advanced Kinai area rose, the productivity in the backward area such as the northeastern and Kantō areas increased by a greater amount. The establishment of water management systems in every corner of the country enabled this growth in productivity throughout Japan. 
In sum, civil engineering projects expanded paddy acreage and promoted the rise of land productivity in Tokugawa Japan. How did local government projects promote the creation of a village community? How, in turn, did wealthy villagers begin to help carry out projects?

\section{DEVELOPMENT OF VILLAGE COMMUNITIES AND CIVIL ENGINEERING PROJECTS}

\section{The Growth and Decline of the Projects of Indigenous Magnates}

Before the Tokugawa period, village communities did not play an important role in managing water resources. In the sixteenth century, powerful individuals carried out civil engineering projects. Indeed, in Kinai, the most advanced region, indigenous magnates usually controlled irrigation and drainage. Although historians refer to the magnate in several ways, such as $\operatorname{dog} \bar{o}$ (powerful local clan), ji-zamurai (vernacular warriors), or shō-ryōshu (minor seigniors), its central feature was performing large-scale cultivation by employing several genin, or servants, who were personally subordinate to the magnate. The indigenous magnates engaged servants to build ponds or canals for irrigation and drainage. Furthermore, the magnates controlled resources in the woodlands. Private facilities for water management and the control of woodlands were important sources of a magnate's regional power. In local settlements, several small peasant households also cultivated their fields, only with their family's labor. Although the peasants were not personal subjects, they had to follow the magnate's orders to obtain permission to use the irrigation facilities and woodlands. Therefore, the peasants provided labor for the maintenance of the facilities (Asao 1967).

Nevertheless, large-scale civil engineering projects by local governments in the "great reclamation" from the sixteenth century undermined the power of local magnates. Note that there were two types of local governments in charge of water control in the Tokugawa period. First, in the regions where a lord, or daimyō, exclusively ruled a large territory, his officials carried out water management and flood control. I call this type of government a "domain government." However, not all the domains had a territory large enough to have sole control over a river. Second, in Kinai, around Kyōto and Ōsaka, and Kantō, around Edo, many domains intermingled with one another. Therefore, a shogunate magistrate, or bugyo, presided over the construction and maintenance of dikes, canals, and ponds for irrigation and drainage in the region (Ōtani 1996, Mizumoto 1993, 267-301). I call this type of government a "magistrate government." In the early seventeenth century, the magistrate government promoted several large-scale projects in Kinai. For example, in 1608 , the great repair work of the Sayama Pond in Kawachi within Kinai improved the irrigation of the surrounding regions. The peasants benefited most from the project since they became less dependent on the private facilities of indigenous magnates. Now, the peasants requested equal treatment of water management. 
Furthermore, Toyotomi's nationwide land survey from 1582 to 1598 registered many former servants who had served indigenous magnates as independent holders of land titles. They also benefited from improvements in infrastructure. Then, in each village, a cooperative community consisting of autonomous peasant households emerged (Asao 1967, Mizumoto 2008, 129-139).

In the advanced regions, the power of indigenous magnates declined as a result of the increase in governmental projects. Nevertheless, in the backward northeastern and Hokuriku regions, the domain government utilized indigenous magnates to develop many paddies and fields. For example, in Mutsu province under the Hirosaki domain government, from 1619 to 1687, if an indigenous magnate developed a new village at his own cost, he was given a fief, or jikatachigyō, of thirty or fifty $k o k u^{7}$ and was then employed as a lesser vassal, or shochigyō samurai. However, since the increase in fiefs did not improve the finances of the domain government, the fief system was abolished in 1687. Afterward, the shochigyo moved to the castle town as samurai and obtained a stipend, or became peasants by returning the samurai title. Then, the domain government directly managed large-scale projects called mikura-ha; until 1730, they established 201 new villages by building canals and reclaiming land from marshes. These projects by the domain government were sharply in contrast with the previous small-scale projects by indigenous magnates (Kikuchi 1977, 70-77, Kikuchi 1986, 635-729). Moreover, in other backward regions, indigenous magnates and samurai vassals carried out civil engineering projects and expanded paddies. For example, in the Aizu domain government, samurai vassals and indigenous magnates established hōkonin-shinden and mitate-shinden, respectively, and in the Akita domain government, samurai vassals developed sashigami-kai (Miura 1983). Nevertheless, as in the Hirosaki domain government, in the late seventeenth century, the shogun and daimyō, or the heads of local governments, removed the vassals and some of the magnates from their fiefs to control the peasants directly. The daimyō provided samurai vassals staying in castle towns with "an amount equivalent to the expected income from that man's original fief” (Gordon 2003, 15). Thereafter, village communities, in cooperation with local governments, played an important role in public investment.

In the seventeenth century, local governments dominated the techniques in these large-scale projects. Until the sixteenth century, the advanced regions of Kinai had had several groups of craftsmen who specialized in building dikes and dams. Local government officials employed them or learned techniques from them (Miura 1984). Furthermore, in the seventeenth century, the shogun and daimyō built castles and dug new mines. The construction techniques developed in these projects were employed in the construction of dikes, canals, and ponds. Government officials were required to have advanced techniques for water management. Therefore, "in guidebooks, or jikata-sho, which instructed officials on how to control people, there were many explanations of techniques for controlling 
rivers and irrigating paddy" (Tsukamoto 1984, 197). Nevertheless, it should also be known that government officials were not able to complete projects without the support of local people who were aware of the detailed conditions of rivers and lands. Hence, the officials usually employed a few villagers as their assistants (Nishida 1984, 228-229).

\section{Civil Engineering Projects by \\ Local Governments and Village Communities}

In Tokugawa Japan, there were two types of construction projects for dikes, canals, and ponds. Go-fushin was carried out at the expense of shogunates or local governments, whereas $j i$-fushin was carried out at the expense of village communities (Ōishi 1960, 75). Furthermore, there were four varieties of go-fushin: first, kōgifushin, whose cost was borne only by the shogunate; second, otetsudai-fushin, where the shogunate ordered domain governments to contribute money and labor to shogunate construction projects; third, kuniyaku-fushin, where the magistrate managed the projects in an area consisting of several small domains by allocating the cost to surrounding villages; and fourth, ryoshu-fushin, where each domain government carried out projects in its own territories. Out of the four varieties of go-fushin, the first three were usually carried out on a temporary basis for disaster recovery or large-scale projects (Ōtani 1996, 133). In kuniyaku-fushin, villagers were sometimes asked to work without receiving wages. The dikes and canals constructed in the project were public goods that benefited villages by preventing floods and improving water management, but the villagers sometimes complained about the "excessive" burden. For example, in 1678, the villages in the shogun domain requested an exemption from providing laborers, since they had already undertaken other government work (Murata 2009).

The activities of village communities were often connected with public investments by local governments. In particular, during the seventeenth century, the domain government carried out river-controlling projects that provided a basis for other projects. For example, in Muko-gun of Settsu province, the Amagasaki domain government built the dikes of the Muko River and dug new ponds and canals. Thereafter, wealthy villagers invested in building branch canals and expanding paddies on the western side of the river. In the process, village communities played an important role. Villagers in the irrigated areas cooperated in order to maintain irrigation facilities and allocate water "equitably." As Mizumoto $(2002,45)$ states, "The civil engineering projects involved several villages in the new irrigation system and strengthened the mutual relationship among the villages." Furthermore, in Etchū province, which has seven major alluvial fans, public investment by the Kanazawa domain government on the construction of the dike to control rivers promoted the expansion of paddies. For example, starting in 1670, the government built a large dike to control the Shō River to prevent floods. This construction encouraged village communities to expand paddies and fields 


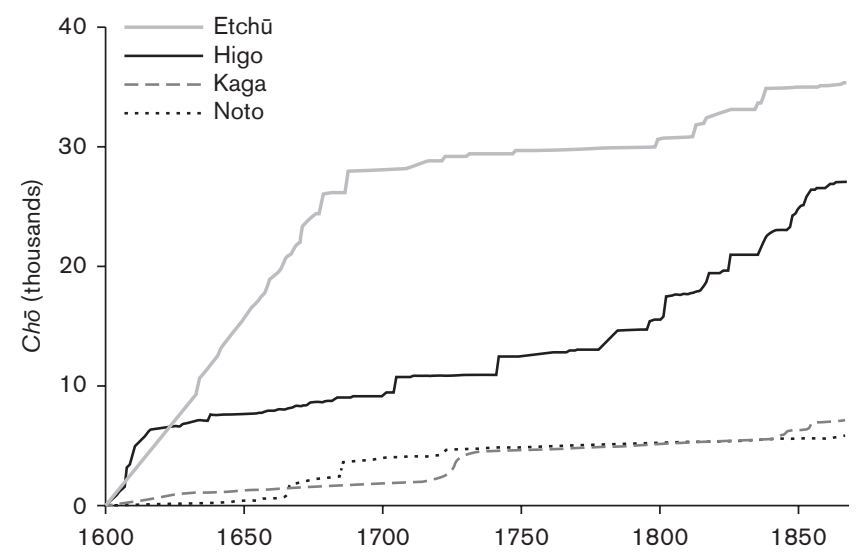

figure 10. Increase in Paddy Acreage in Kaga, Noto, Etchū, and Higo Provinces

Source: The database mentioned in the text.

significantly. Imamura (2014) shows that the new arable lands were created not only by establishing new villages on the alluvial plains, but also by increasing paddy acreages in existing villages. Village communities supported the projects. After 1660 , they had to provide thirty workers per one hundred koku. Furthermore, "in principle, villagers living downstream were in charge of cleaning the river bottom to maintain the banks (kawayoke) and maintaining canals, although the local governments provided subsidies if the cost was too high" (Saeki 2007, 153). ${ }^{8}$ In Etchū province, paddy acreage increased by 34,400 cho from around 1600 to 1872 , which is in contrast with a moderate increase of only sixty-eight hundred cho in Kaga province under the same local government, namely, the Kanazawa domain government (Figure 10). Since Kaga province was a more advanced region, there was only a bit of room for the expansion of paddies.

\section{Merchant-Initiated Reclamation}

In Tokugawa Japan, there were some individual merchants who promoted civil engineering projects. Furthermore, they sometimes became landlords of the newly reclaimed land and collected rents from the tenants. These merchants may correspond to entrepreneurial individuals in England and the Netherlands that undertook land improvement projects. In England, landlords promoted enclosures to improve productivity and raise rents, and farmers also brought about land improvements through drainage, fencing, or the erection of new buildings. Then, farmers had the "tenant right" to be compensated for their investments (Overton 1996, 162-184). In the Netherlands, wealthy town dwellers made large-scale investments to reclaim new polders, since "large landownership was dominant there from the outset" (van Bavel 2001, 17). These civil engineering projects increased 
agricultural production by expanding cultivated land and improving land or labor productivity. In Japan, however, the activities of merchants were not always praised. They sometimes contradicted the interests of the shogunate and domain government. Matsuyoshi (1936/1955) states that "merchant-initiated reclamation (chōnin ukeoi shinden)" undermined the "feudal agrarian system." Nevertheless, the policies of shogunate governments on merchants' projects were not consistent. In 1687 , the government prohibited merchant-initiated reclamation. In 1722, merchants were permitted to develop new paddies and obtain rents from tenants since the shogunate hoped that the new villages built by merchants would stabilize rural society, by absorbing the surplus population in the surrounding villages (Kimura 1964, 52-54, Öishi 1973, Kikuchi 1977, 516). For example, on the eastern side of the Muko River, merchants from Ōsaka and Amagasaki invested in building new paddies in the seventeenth century (Mizumoto 2002, 48-50).

Nevertheless, the merchants' projects in Japan are not regarded as similar to entrepreneurial individuals' projects in England and the Netherlands for three reasons. First, their contributions were limited. The database of civil engineering projects shows that the acreage constructed by merchants was only less than $5 \%$ and the projects were concentrated around big cities, such as Edo and Ōsaka. Second, many government officials and scholars continued to criticize merchants' projects. Even after the shogunate's authorization, Kyūgu Tanaka blamed merchants for "deceiving and slandering others for money and engaging themselves just in obtaining their own profit" and recommended utilizing "the knowledge in villages and hamlets" (Tanaka 1721/1996, Kurachi 2008, 75-78). Finally, whereas villagers often resisted the entrepreneurial projects in Europe (Blum 1978), village communities usually helped merchants create new paddies in Japan. In practice, villagers used their knowledge to gain profits even from merchants' projects. Nakai states that, in new villages, merchant landlords maintained social order and promoted agricultural production with the strong connection with surrounding village communities, and therefore, "merchants carried out the projects by parasitizing existing village communities even in the most commercialized region around Ōsaka, although it is supposed that the tenancy relationship in merchantinitiated reclamation was contractual and free from communal constraint" (Nakai 1956, 219). Thus, villagers supported civil engineering projects by merchants, as well as by local governments.

\section{The Rise of Contributions by \\ Village Communities in the Nineteenth Century}

In a later period, the contributions of village communities increased further, and the distinction between go-fushin by the local government and ji-fushin by village communities became obscure. When the scale of go-fushin projects was not so large, wealthy villagers sometimes took the initiative in the project. Indeed, gofushin projects executed by local governments were not always effective. In 1721, 
Tanaka criticized go-fushin for its inefficiency and recommended a procedure to carry out go-fushin by which local villagers first requested a project and then local governments assessed it. If the project was found to be good, the government would subsidize it. In these cases, the villagers provided labor and shared the financial burden with the government. Nagatsuma calls this "the subsidization of government construction and maintenance" (Nagatsuma 2001, 35).

In the paddy expansion from the 1820 s onward, the role of wealthy villagers was prominent. Many domain governments had suffered from financial debts that were so severe that they were not able to afford to pursue civil engineering projects. Meanwhile, some villagers had accumulated wealth and carried out large-scale projects without support from their local governments. To avoid the risk of a shortfall in capital, villagers sometimes formed a new type of organization for investment. Yanagita, a famous folklorist, contrasts "cooperative" construction of new paddies with projects "led by one leader" (Yanagita 1931/1991, 247); thus, cooperatively reclaimed districts often have place names such as Sōbiraki (literally meaning "collectively reclaimed"). Kikuchicalls this cooperative organization hyakushō yoriai shinden (peasant cooperation to develop new paddies), which collected from many peasants like a joint-stock company and allocated new paddies according to the amount contributed (Kikuchi 1977, 304-305). For example, in Bizen province in 1852, a peasant cooperation reclaimed land from the sea to build $730 \mathrm{cho}$ of paddies. It collected 1,015 $\mathrm{kan}$ worth of silver from 336 peasants. However, the cooperative organization did not eliminate the risk entirely. The manager spent his own entire fortune on the project and became bankrupt.

By the development of techniques as well as the improvement of finance, village communities contributed to civil engineering projects in the nineteenth century. At that time, some villagers had acquired advanced techniques for constructing dikes, canals, and ponds. As mentioned earlier, in the seventeenth century, government officials nearly monopolized water management techniques. However, afterward, villagers improved their techniques and the high-level skills began to spread directly to other villagers. "As villagers in several regions communicated with each other and broadened their perspectives, their knowledge and skills were able to be interconnected without the mediation of government officials" (Tsukamoto 1984, 225). Then, to carry out go-fushin, some local governments employed capable villagers. For example, in Etchū province, Dōsan Shiina, born in a family of wealthy peasants in 1790, constructed several canals until he was in his thirties. Since he displayed great talent in these projects, the Kanazawa domain government asked him to give them advice on the construction and maintenance of dikes and canals in 1829, and appointed him as a manager of development of new paddies. Thereafter, he directed several projects in Etchū, Noto, and Kaga provinces, including Jūni-kanno canal irrigating 652 chō. Shiina had sophisticated techniques for planning a waterway route, measuring slopes, and building facilities. Although 
it is not known as to who taught him these skills, there must have been several opportunities for wealthy villagers to learn advanced techniques in rural society. For instance, in the same province, Nobuyoshi Ishikuro, born in another family of wealthy peasants in 1760 , studied Japanese mathematics and astronomy, and acquired enormous skills in measurement and calculation (Jūnikanno-yōsuitochikairyōku 1985).

Furthermore, wealthy villagers sometimes took the initiative in carrying out many go-fushin activities, which were supposed to be done by the local government. For instance, in Higo province, under the Kumamoto domain government, a regional and originally nongovernmental association of villages (tenaga) managed almost all civil engineering projects. Then, wealthy peasants (sou-shōya), who managed the association, were treated as local government officials. Since the tenaga was incorporated into the administrative system of the local government, civil engineering projects were usually regarded as "public." The MAC (1926) labels them as "governmental," and, furthermore, Kimura states that all projects in Higo province were managed by the Kumamoto domain governments (Kimura 1964, 179-181). However, the tenaga, rather than the local government, carried out projects. Yoshimura states that "in the early Tokugawa period, authorities of the shogun and daimyō executed civil engineering projects for river control and water management by organizing teams of vassals and the labor services of peasants. These were the most important public activities and duties by such authorities in order to justify their control over peasants. Nevertheless, in later periods, the civil engineering projects were conducted not by the authorities of the shogun and daimyō, but by the tenaga" (Yoshimura 2013, 113). The development of regional associations promoted civil engineering projects. Yoshimura indicates that in Higo province, the nineteenth century was "the age of civil engineering for water management." Some tenaga built several canals for expanding new fields and others reclaimed land from Yashiro Bay on a large scale. For example, Yabe tenaga planned to build Tsūjunkyō canal consisting of a ditch of forty-two kilometers, a siphon, and an aqueduct. Since the tenaga was creditworthy enough to borrow from the domain government, wealthy villagers, and merchants, it was able to pay the huge construction costs. The tenaga refunded the debt from the profit of newly reclaimed paddies (Yoshimura 2013, 405, 408-453). Then, the paddy acreage in Higo province increased significantly, as figure 10 shows.

Major contributions by wealthy villagers to civil engineering projects continued beyond the political transformation by the Meiji Restoration in 1868. Many projects were carried out with private capital. For example, in 1879, the Aichi prefecture government permitted two wealthy villagers, Hyomatsu Okamoto and Ihachiro Iyoda, to build canals for irrigating infertile fields in Hekikaigun. To carry out this project, Okamoto and Iyoda invested their own fortune. Furthermore, they persuaded five others to join the project by explaining the profitability of the investment. In 1881, they accomplished the construction, and 
the canal was named "Meiji canal." It created eighty-eight hundred chō of new paddies and improved the hydrological condition of forty-five hundred cho of old paddies. The large cost of the project was compensated by the income from distributing water. Okamoto and Iyoda had spent too much money in this project and were bankrupt, while the five investors gained profit by obtaining new paddies (Kondo 1929, 193-197, Hatate 1977, 105-110). Until 1881, the Japanese economy had grown based on brisk economic activity, mainly in the countryside. As Saito and Tanimoto state, "The period between the early nineteenth century and Matukata Deflation (1881-1886) was the period of rural centred development" (Saitō and Tanimoto 1989, 226). The increase in civil engineering projects sponsored by wealthy villagers was an aspect of the "rural centred development." However, a rural depression caused by the Matsukata Deflation hindered the accumulation of wealth by villagers. Thereafter, the pace of paddy acreage growth slowed down. The growth of paddy acreage stagnated until the 1910s, when paddy acreage started to increase greatly, again. While from 1874 to 1880 , paddy fields expanded by 914 chō per year, from 1880 to 1905 , it extended by 536 chō per year. Then, from 1905 to 1930, paddy acreage increased 1,352 chō per year (Umemura et al. 1966, 216). However, this time, government funds rather than the private capital of wealthy villagers played a very important role. With the Reclamation Assistance Act of 1919, the government began to subsidize the rent of the capital for the project. Furthermore, after the Ministry of Agriculture and Commerce of Japan issued a Notification to Subsidize Projects for Improving Irrigation and Drainage (1923), a government fund was injected into large projects affecting five hundred hectares or more (Imamura 1977).

\section{COMMUNAL FUNCTIONS OF JAPANESE VILLAGES}

\section{Functions of Village Communities}

In Tokugawa Japan, village communities or leagues of villages played crucial roles in many civil engineering projects. The principal reason for the positive role of village communities is that paddy cultivation in Japan necessitated close cooperation within and among villages. Since every paddy in a village shared an irrigation system, the mismanagement of one plot affected the entire village adversely. One household's negligent water management could interfere with its neighbors' water supply (Watanabe 2008, 81-85, Kanzaka 2018). Reflecting the communal character of cultivation, Japanese peasants did not believe that they had exclusive rights to a plot even if they cultivated it. At the end of the nineteenth century, a Japanese peasant stated, "the surface layer of the land belongs to me, the middle layer belongs to my village, and the deepest layer belongs to Heaven" (Sakane 2011, 137). They still had the idea that possession in the village should be common. Yanagita states, "the idea that 'land in a village should be used by the [members of] the village' has 
its origin in history and still has a surprisingly strong influence in today's society" (Yanagita 1931/1991, see also Sakane 2011, 140-141). This notion of property rights did not match the European view. Therefore, even after the Japanese made the Meiji Civil Code by studying European laws in 1898, customary rules continued to control life in each village. Peasants were expected to work together and help one another. In the beginning of the twentieth century, village communities still had effective control over land transfers and field utilization. Even if some outsiders, such as town merchants, became absentee landlords, the villagers required the landlords and their tenants to follow the rules of cultivation of the village (Saito 1989, 223-254). Therefore, landlords were not able to buy and sell land freely.

In the Tokugawa period, strong village communities sometimes prevented land-improving projects but, other times, promoted agricultural development. In some cases, villagers opposed the development of new paddies, since this development would reduce the amount of grassland needed to fertilize paddies. In this respect, Japanese peasants seem to have behaved in the same way as many European peasants did, in resisting the enclosure of commons (Blum 1978, 292). Tokugawa peasants made a fertilizer called karishiki from grass and young leaves. The area of grassland and mountain necessary for providing the fertilizer was ten times larger than the size of the cultivated land area. Therefore, for example, when there was a plan to turn grassland into paddies in Yamashiro province in 1702, villagers opposed the plan because it would cause a shortage of fertilizer as well as the runoff of soil. Furthermore, at the beginning of the eighteenth century, a shogunate official lamented that "it has become difficult to find land on which new paddies could be developed," and stated that "recently grassland [magusaba] has been turned into paddies. Since the grassland is the place that supplies fertilizer and feeds horses . . . this type of new paddy development is unfavorable" (Mizumoto 2003, 70-71).

Meanwhile, in other cases, cooperation in villages based on communal property supported the construction and maintenance of public goods. Indeed, village communities were suitable for improving and maintaining irrigation facilities. Hayami and Godo (2002) state that communities were usually superior to markets and the state in the supply of "local public goods" because "the community relationship is effective in preventing free-riders." Members who did not join collective works, such as the construction and maintenance of irrigation canals, would be severely sanctioned by the village. In addition, Yanagita states that "the negligence of just one or two people will cause failure in community-based works, such as destroying insects and weed seeds and repairing canals and roads . . Japanese villages avoid this risk by old customs, while many other law-governed countries do this by enactment" (Yanagita 1931/1991, 261-262, see also Sakane 2011, 138-139). Since maintenance systems based on village communities worked well, local governments and wealthy villagers invested in water management facilities. 


\section{The Function of Regional Society}

Close connections in Tokugawa Japan were not just found within each village. Several villages in a region were closely interconnected. The villages had to cooperate to maintain the facilities and allocate water. Tokugawa Japan had many leagues of villages that cooperated to control irrigation and drainage. The league also preserved commons and worshiped a common local Shinto deity. For example, in Kizu-gō of Yamashiro province, there was a league of nine villages consisting of about eleven hundred households. Since the territory of the nine villages was divided into more than ten lordships, the league played a key role in preserving order. The league kept control of a total of eleven irrigation ponds and five canals and rivers. About twenty-five village officials in this league frequently communicated with one another to reconcile the interests of each village. The officials usually joined the meetings of the league more frequently than every other day (Mizumoto 1993, 154-159).

Within the league, however, villages not only cooperated, but also fought over the allocation of water. Villages that were situated upstream or whose ancestral members had greatly contributed to building the facilities had an advantage in accessing irrigated water (Kitamura 1950, 208-214). To maintain or to eliminate discrimination, each village pursued its own interests. Furthermore, the construction of new canals and ditches also caused trouble. The establishment of a new sluice gate on a river could prevent downstream villages from being sufficiently irrigated. In addition, new drainage ditches could emit water and create a nuisance for other villages. Therefore, there were many disputes over irrigation and drainage (yōsui-sōron) in Tokugawa Japan. The irrigation-drainage disputes were fought and settled in three characteristic ways. First, players in the disputes were usually not individuals, but village communities. When they litigated disputes, both the plaintiff and the defendant were usually village communities. Especially in the first half of the eighteenth century, most documents describing the rights and practices of irrigation and drainage were signed in the name of the village (Watanabe 2007, 181-185, Mizumoto 1993, 4-7).

Second, many disputes were settled out of court. Prominent figures and officials staying in neighboring villages arbitrated several conflicts between villages. As mentioned before, officials in the same league of villages frequently communicated with one another in daily life. This close relationship helped bring about reconciliations. Certainly, some disputes went to government court, but it was not unusual for government officials not to decide but instead to ask the village officials to reconcile (Watanabe 2007,182 ). For example, the disputes over canals and commons between several villages in late-eighteenth-century Odawara domain government were settled using the following process. Since voluntary reconciliation by neighboring villages had failed, the two parties brought the matter before the court of the domain government. However, government officials did not make a decision, but instead ordered the prominent figures of neighboring villages to 
arbitrate the dispute. Then, the arbitrators managed to settle it. Thus, local governments and village communities cooperated to maintain the social order. On the one hand, "the government officials utilized practical knowledge and functions for the reconciliation of the arbitrators based on village society"; on the other hand, "the arbitrators negotiated with parties backed by the authority of the local government" (Mizumoto 2008, 327-328).

In early modern Japan, many civil engineering projects were carried out, and paddy acreage was expanded, especially from the sixteenth century to 1680 , from 1722 to 1736 , and from the 1820 s to 1880 . Then, until the beginning of the twentieth century, each individual district throughout the country of Japan had developed its own appropriate irrigation system. From the seventeenth century to the nineteenth, village communities or leagues of villages played an important role in many civil engineering projects. The activities of village communities were connected with public investments by local governments through irrigation and drainage networks. Government projects made it possible for villagers to create new paddies and fields. Furthermore, in practice, village communities sometimes initiated the promotion of public projects subsidized by the local government. The strength of a village community lay in the irrigation and drainage system, which were closely connected with the production activities of each household within a village.

Even after Western-style Civil Code was established in 1898, customary law governed many land transactions and water management in rural society. However, in the beginning of the twentieth century, well-developed irrigation systems based on cooperation among and within village communities became regarded as an obstacle to the growth of agriculture in Japan. The Ministry of Agriculture and Commerce of Japan believed that customary irrigation rights of village communities prevented the expansion of paddies and caused instability in the water supply, and tried to eradicate these customary rights. Furthermore, in 1923, "to modernize irrigation facilities and to deny customary irrigation rights effectively," the Ministry decided to carry out large-scale projects supported by the national budget (Imamura 1977, 138). Whereas, in the Tokugawa period, investments by local governments were promoted and supported by the community-based irrigation mechanism, in the twentieth century, the government made investments to abolish the traditional irrigation system and established a "modernized" water management mechanism.

\section{NOTES}

This work is supported by JSPS KAKENHI grant number $15 \mathrm{Ko} 3589$.

1. One chō is $9,917.4 \mathrm{~m}^{2}$ and is almost equal to one hectare. Hence, one chō is 2.45 acres. However, the actual area of $c h \bar{o}$ varied according to place and time in the Tokugawa period. 
2. Okura-shō (1927) provides paddy acreage data from 1716 to 1748 (the Kyoho to Enkyo eras), although its original source is unknown. Using this data, the paddy acreage in the early eighteenth century is calculated as $1,643,450$ cho, whereas the total acreage of arable land is $2,969,714$ cho .

3. So far, the revised acreage has been regarded as almost $50 \%$ larger than the former acreage (Sasaki 2016), since APDLTR (1953-1957) records the revised paddy acreage as 2,622,593 chō and the former acreage as 1,701,149 chō. However, this calculation is not correct. The former acreage does not include the paddy acreage in the Nagasaki and Ishikawa prefectures. Therefore, to calculate the increase from the former acreage to the revised acreage, the acreage of these two prefectures should also be excluded in the estimation of revised acreage. Then, the revised acreage is rectified to 2,423,474 chō. Hence, the increase rate is $42.9 \%$. Furthermore, the former paddy acreage, including that in the omitted districts, was estimated as $1,842,104$ chō.

4. The estimation is different from that of Miyamoto since he shows that arable land increased more in the late seventeenth century than it did in the early period, and there was not a rapid increase of arable land between the 1720 and 1730 (Miyamoto 1999, 38). Since he calculates the field expansion without considering the scale of each project, Miyamoto underestimates the effects of great projects in the early seventeenth century and from the 1720 s to the 1730 .

5. It is because in land survey investigations, peasants hid some paddies and fields to evade tax and, furthermore, the domain government that conducted the land surveys did not report the real situation to the shogunate. Kawamura 1984, 159, 246, 263.

6. Kokudaka of 1697-1702 in the Echizen province is considered much higher than the real productivity; a contemporary stated that "the kokudaka had been determined improperly to pretend about the high productivity of the domain." Fukui-ken 1994.

7. One koku is equal to 180 liters. However, the actual volume of koku varied according to place and time.

8. In 1732, the shogunate also stated that each village had to provide fifty workers per $100 k o k u$ at its own cost, and the shogunate would give wages to additional laborers.

\section{REFERENCES}

Akita-ken ECLIH (Editing Committee of Land Improvement History) (1985). Akitaken Tochi-kairyō-shi (A History of Land Improvement in Akita). Akita, Akitaken Tochikairyō Jigyō-rengo-kai.

APDLTR (Association for Publishing Documents about Land Tax Reform) (1953-1957). Meiji-shonen Chiso-kaisei Kiso-shiryō (Basic Document about Land Tax Reform during the Early Meiji Period). 3 vols. Tokyo, Yūhikaku.

Asao, Naohiro (1967). Kinsei Hōken-shakai no Kiso-kōzō (The Basic Structure of Early Modern Feudal Society). Tokyo, Ochanomizu Shobō.

Blum, Jerome (1978). The End of the Old Order in Rural Europe. Princeton, Princeton University Press.

Booth, Anne, and R. M. Sundrum (1985). Labour Absorption in Agriculture. Oxford, Oxford University Press.

Fukui-ken (1994). Fukui-kenshi: Tsūshihen3, Keisei 1 (A History of Fukui Prefecture: Early Modern, Part 1). Fukui, Fukui-ken.

Gordon, Andrew (2003). A Modern History of Japan: From Tokugawa Times to the Present. Oxford, Oxford University Press.

Hatate, Isao (1977). "Tochi-Kairyō wo Ninatta Hitobito" (People Who Carried Out Land Improvement Projects). In Imamura et al. 1977. 
Hayami, Yūjiro, and Yoshihisa Godo (2002). Nōgyō-keizai-ron (Agricultural Economics). 2nd ed. Tokyo, Iwanami Shoten.

Imamura, Ikuko (2014). Kinsei-shoki Kaga-han no Shinden-kaihatsu to Kokudaka no Kenkyū (A Study of the Development of New Paddies and the Kokudaka of Kanazawa Domain Government in the Early Tokugawa Period). Toyama, Katsura Shobō.

Imamura, Naraomi (1977). “Tochi-Kairyō Eno Kokka no Tōjō” (The Entry of the National Government into Land Improvement Projects). In Imamura et al. 1977.

Imamura, Naraomi, Toshiro Sato, Hiroyasu Shimura, Satoshi Tamaki, Eijuro Nagata, and Isao Hatate, eds.(1977). Tochi-kairyō Hyakunen-shi (One Hundred Years of History of Land Improvement). Tokyo, Heibonsha.

Ishikawa, Shigeru (1967). Economic Development in Asian Perspective. Tokyo, Kinokuniya.

Ishikawa-ken ECLIH (1986). Ishikawa-ken Tochi-kairyō-shi (A History of Land Improvement in Inshikawa). Ishikawa, Ishikawa-ken Tochi-kairyō-jigyō Rengō-kai.

JSCE (Japanese Society of Civil Engineering) (1936). Meiji-izen Nihon Doboku-shi (A PreMeiji History of Civil Engineering in Japan). Tokyo, Iwanami Shoten.

Jūnikanno-yōsui-tochikairyōku (1985). Jūnikanno Yōsui-shi (A History of Jūnikanno Canal). Toyama, Chūetsu.

Kanzaka, Junichi (2018). "The Scattered and Intermingled Field System of Japan Compared to the Open-Field Systems of Europe." In Peasants and Their Fields: The Rationale of Open-Field Agriculture, c. 70o-180o, edited by C. Dyer, E. Thoen, and T. Williamson. Turhout, Belgium, Bropls.

Kawamura, Hirotada (1984). Edo Bakufu-sen Kuniezu no Kenkyū (A Study of Pictorial Maps Collected by the Edo Shogunate). Tokyo, Kokon Shoin.

Kikuchi, Toshio (1977). Shinden Kaihatsu (Development of New Paddies). Tokyo, Kokon Shoin.

- - (1986). Zoku Shinden Kaihatsu (Development of New Paddies, Part 2). Tokyo, Kokon Shoin.

Kimura, Motoi (1964). Kinsei no Shinden-mura (Newly Developed Villages in the Tokugawa Period). Tokyo, Yoshikawakōbunkan.

Kitamura, Toshio (1950). Nihon Kangai-suiri-kankō no Sshiteki-kenkyū (A Historical Study of Customs of Irrigation and Water Management). Tokyo, Iwanami Shoten.

Kurachi, Katsunao (2008). Tokugawa-Shakai no Yuragi (The Destabilization of Tokugawa Society). Tokyo, Shōgakkan.

Kondo, Sentaro (1929). Meiji-Nenkan Kangai Haisui Jigyō Shiryō (Record of the Project for Irrigation and Drainage in the Meiji Period). Tokyo, MAC.

MAC (Ministry of Agriculture and Commerce) (1909). Ta no Kangai-haisui ni Kansuru Jōkyō Chōsa (Survey on the Irrigation and Drainage of Paddies). Tokyo, MAC.

- - (1926). Kyūhan-jidai no Kouchi-kakuchō-kairyō-jigyō ni Kansuru Chōsa (Research on the Expansion and Improvement of Fields in the Tokugawa Period). Tokyo, MAC.

Matsuyoshi, Sadao (1936/1955). Shinden no Kenkyū (A Study of New Paddies). Tokyo, Yūhikaku.

Miura, Kaiichi (1984). "Chūsei no Doboku to Shokunin-Shūdan” (Civil Engineering and Craftsmen Group). In Doboku (Civil Dngineering), edited by Akeshi Amakasu et al. Tokyo, Nihon-hyōron-sha. 
Miura, Tetsuro (1983). Akita-han Niokeru Shinden Kaihatsu (The Development of New Paddies in Akita Domain). Tokyo, Kokon Shoin.

Miyamoto, Matao (1999). "Quantitative Aspects of the Tokugawa Economy." In The Economic History of Japan, edited by Akira Hayami, Osamu Saitō, and Ronald P. Toby. Oxford, Oxford University Press.

Mizumoto, Kunihiko (1993). Kinsei no Gōson-jichi to Gyōsei (Autonomy and Administration of Village Leagues in the Tokugawa Period). Tokyo, Tokyo University Press.

- - (2002). Ezu to Keikan no Kinsei (Pictorial Maps and Landscapes in the Tokugawa Period). Tokyo, Azekura Shobō.

- - (2003). Kusa-yama no Kataru Kinsei (Grassland Mountains in Tokugawa Japan). Tokyo, Yamakawa Shuppansha.

- - (2008). Tokugawa no Kokka Dezain (Tokugawa's Design for State Building). Tokyo, Shōgakukan.

Murata, Michihito (2009). Kinsei no Yodogawa Chisui (Water-Control of the Yodo River in the Tokugawa Period). Tokyo, Yamakawa Shuppansha.

Nagatsuma, Hiroshi (2001). Hojokin no Shakai-shi (A Social History of Subsidy). Kyoto, Jinbun Shoin.

Nakai, Nobuhiko (1956). "Shōnin-Jinushi no Shomondai" (Several Problems on Merchant Landlords). In Meiji-ishin to Jinushi-sei (Meiji-Restoration and Landlord System), edited by Rekishigaku-kenkyūkai. Tokyo, Iwanami Shoten.

Nakamura, Satoru (1968). Meiji-ishin no Kisokōzō (Basic Structures of the Meiji Restoration). Tokyo, Mirai-sha.

Niigata-ken ECLIH (1986). Niigata-ken Tochi-kairyō-shi (A History of Land Improvement in Niigata). Niigata, Niigata-ken Tochi-kairyō Jigyō-rengō-kai.

Nishida, Masaki (1984). "Kawayoke to Kuniyaku Fushin" (Controlling River and Government-Sponsored Constructions). In Doboku (Civil Engineering), edited by Takeshi Amakasu et al. Nihon-hyōron-sha.

Ōishi, Shinzaburo (1960). "Bakuhan-Taisei-Shakai no Kōzō” (The Structure of Shogunate System Society). Rekishigaku-kenkyū 242:72-80.

- - (1973). "Kinsei-Chūki no Shinden Seisaku" (The Policy of Creating New Paddies in the Middle of the Tokugawa Period). Gakushūin Daigaku Keizaironshū 10 (3): $59-76$.

Ōkura-shō (1927). Dai-nippon Sozei-shi (Financial History of Great Japan). Tokyo, Okura-shō.

Ōtani, Sadao (1996). Edo-bakufu Chisui-shi Seisaku-shi no Kenkyū (A Study of the History of the Tokugawa Shogunate's Policy of Controlling Rivers). Tokyo, Yūzankaku.

Overton, Mark (1996). Agricultural Revolution in England: The Transformation of the Agrarian Economy, 1500-1850. Cambridge, Cambridge University Press.

Saeki, Yasukazu (2007). Kinsei Tonami-heiya no Kaihatsu to Sanson no Tenkai (The Exploitation of the Tonami Plain and the Development of Dispersed Villages in the Early Modern Period). Toyama, Katsura Shobō.

Saito, Hitoshi (1989). Nōgyō-mondai no Tenkai to Jichi-sonraku (The Development of Agrarian Programs and Autonomous Villages). Tokyo, Nihonkeizai Hyōronsha.

Saitō, Osamu (1988). "Daikaikon, Jinkō, Shōnō Keizai" (Great Reclamation, Population, and Peasant Economy). In Keizai Shakai no Seiritsu (Emergence of Economic Society), edited by Akira Hayami and Mataro Miyamoto. Tokyo, Iwanami Shoten. 
Saitō, Osamu, and Masayuki Tanimoto (1989). “Zairai-Sangyō no Sai-Hensei” (Restructure of Indigenous Industries). In Kaikō to Ishin (The Opening Ports and the Meiji Restoration), edited by Mataji Umemura and Yuzo Yamamoto. Tokyo, Iwanami Shoten.

Sakane, Yoshihiro (2011). Ie to Mura: Nihon Dentō-shakai to Keizai Hatten (Family System and Village: Economic Development and Japanese Traditional Society). Tokyo, Nōsangyoson Bunkakyōkai.

Sasaki, Hiroshi (2016). Chiso-Kaisei to Meiji-Ishin (Land Tax Reform and Meiji Restoration). Tokyo, Yūshisha.

Tanaka, Kyūgu (1721/1996). Minkan-seiyō. Revised by Sunao Murakami. Tokyo, Yūrindo.

Tokunaga, Mitsutoshi (1997). Nihon Nōhō-shi Kenkyū (A Study of Cultivation Methods in Japan). Tokyo: Nōsangyoson Bunkakyōkai.

Totman, Conrad (1998), The Green Archipelago: Forestry in Pre-Industrial Japan. Athens, Ohio University Press.

Toyama-ken ECLIH (2004). Toyama-ken Tochi-kairyō-shi (A History of Land Improvement in Toyama). Toyama, Toyama-ken Tochi-kairyō-jigyō Rengo-kai.

Tsukamoto, Manabu (1984). "Yōsui-Busin" (The Construction of Canals). In Doboku (Civil Engineering), edited by Takeshi Amakasu et al. Nihonhyōron-sha.

Umemura, Mataji, Saburo Yamada, Yujiro Hayami, Nobukiyo Takamatsu, and Minoru Kumazaki (1966). Agriculture and Forestry, Estimates of Long-Term Economic Statistics of Japan. Vol. 9. Tokyo, Tōyokeizai Shinpōsha.

Van Bavel, Bas J. P. (2001). "Land, Lease and Agriculture: The Transition of the Rural Economy in the Dutch River Area from the Fourteenth to the Sixteenth Century." Past and Present 172:3-43.

Watanabe, Takashi (2007). Gōnō, Sonraku-kyōdotai to Chiikishakai (Wealthy Peasants, Village Communities, and Regional Society). Tokyo, Kashiwa Shobō.

- - (2008). Hyakushō no Chikara (Power of Peasants). Tokyo, Kashiwa Shobō.

Yanagita, Kunio (1910/1976). Jidai to Nōsei (Agricultural Policy throughout the Ages). In Yanagita Kunio Zenshū (Collected Works of Yakagita Kunio), vol. 29. Tokyo, Chikuma Shobō.

- - - (1931/1991). Nihon Noumin-shi (A History of Japanese Peasants). In Yanagita Kunio Zenshū, vol. 29. Tokyo, Chikuma Shobō.

Yoshimura, Toyo'o (2013). Nihonkinsei no Gyōsei to Chiikishakai (Civil Administration and Regional Society in Early Modern Japan). Tokyo, Azekura Shobō. 